\title{
Influence of TOEIC on Teachers and Students at Tertiary Level
}

\author{
Chen Mei-Ling ${ }^{1}$ and Hung Li-Mei ${ }^{2}$ \\ ${ }^{1}$ Department of Applied English, Hung-Kuang University, Taicung City, Taiwan \\ ${ }^{2}$ Department of Hospitality Management, Hung-Kuang University, Taicung City, Taiwan \\ mlchen@hk.edu.tw, hlm@sunrise.hk.edu.tw
}

\begin{abstract}
This study examined the washack of the TOEIC on English teaching and learning in Taiwan. Three hundred and twenty- six college students and fifty teachers from a university of technology participated in the study. A survey was used to gather both quantitative and qualitative data. The findings indicated that most of the students agreed that the TOEIC had positive influences on their learning. Teachers commented that the TOEIC influenced their class activities and teaching materials to some degree.

Index Terms - Test of English for International Communication (TOEIC), Student perceptions, Washback
\end{abstract}

\section{Introduction}

Since the first the Test of English for International Communication (TOEIC) was available in 1979, more than 10,000 corporations worldwide use the TOEIC test to make important decisions (Educational Testing Service, 2010). In 2010, more than six million people registered for the TOEIC, and the number of TOEIC test takers in Taiwan has increased by $18 \%$ (Educational Testing Service, 2010). The TOEIC test gained prominence within the field of English proficiency tests in Taiwan. More than 20 thousand people took the test every year. Increasingly, more universities have adopted the TOEIC as one of the recognized exit English examinations in Taiwan (Pan, 2010).

As a great number of test takers have registered for taking the TOEIC and the widespread use of the TOEIC at the universities in Taiwan, it's necessary to examine the washack of the TOEIC on English teaching and learning at the tertiary level. Towards this end, two research questions were posed:

1. What are students' perceptions of the impact of TOEIC on

their English learning?

2. What are teachers' perceptions of the impact of TOEIC on

their English teaching?

\section{Literature Review}

\section{A. The Test of English for International Communication}

The TOEIC test, developed by Educational Testing Service (ETS), is an English language proficiency test for people whose native language is not English. Offered in more than 165 countries around the world, the TOEIC test is used by over 10,000 corporations, educational institutions and government agencies. The TOEIC test is the world's leading test of English language proficiency in a workplace context (ETS, n.d.a).

\section{$B$ English Education at the Tertiary Level in Taiwan}

There are two tracks of higher education in Taiwan. They are general universities and colleges supervised by the Department of Higher Education and the universities and colleges of technology supervised by the Department of Technological and Vocational in the Ministry of Education (MOE).

Since English education at the tertiary level is not regulated by the MOE, universities can independently decide the number of credits and English teachers have the freedom to choose their own instructional materials, develop their own course syllabi, and set the standards for evaluating student achievement.

In order to enhance students' English proficiency and global market competiveness, the Ministry of Education (MOE) encouraged all higher educational institutions to adopt English proficiency graduation requirement. Students are asked to achieve a specific level of proficiency in one of the major standardized English proficiency tests. Some of the major tests include the locally developed criterion-referenced English proficiency test General English Proficiency Test (GEPT), which was developed by the Language Training \& Testing Center (LTTC), Test of English for International Communication (TOEIC) and Test of English as a Foreign Language (TOEFL) developed by Educational Testing Service (ETS), and International English Language Testing System (IELTS).

\section{Methodology}

The researchers invited students and English teachers from one vocational university in Taiwan to participate in the study. This university requires English majors and no-English majors to pass a certain level of English proficiency tests such as the Test of English for International Communication (TOEIC) and the General English Proficiency Test (GEPT) as a degree requirement. The questionnaires with an accompany cover letter were delivered in person to the instructors in Freshmen English and Sophomore English classes. There was a return rate of $93 \%$, with 352 students returning their questionnaires. Of these, 326 questionnaires were valid and used in the final analysis. 
All full-time and part-time instructors teaching Freshmen English and Sophomore English courses were invited to participate in the study. Fifty teachers returned their questionnaires.

\section{Results \& Conclusion}

The results indicated that of the 326 participants, 117 (36\%) strongly agreed or agreed that the TOEIC induced fear, pressure and anxiety on them. 39 (11\%) strongly agreed or agreed that preparing the TOEIC deprived their time in studying other subject matters. Most of the participants (52\%) strongly agreed or agreed that the TOEIC increased their motivation to learn English. 36\% strongly agreed or agreed that they listened more carefully to the teacher in English class. More than half (52\%) agreed that they would change the way they learn English in order to pass the TOEIC. Most of the participants (62\%) agreed that the TOEIC improved their English proficiency to a high level. $116(36 \%)$ strongly agreed or agreed that the TOEIC increased their interest in learning English.

When teachers were asked about the impact of TOEIC on their teaching, forty- one ( $82 \%$ ) teachers commented that the TOEIC had certain influence on their teaching, and only $4 \%$ of the teachers stated that the TOEIC had no influence. As for the aspects of teaching influenced by the TOEIC, more than $80 \%$ of the teachers agreed that the TOEIC would influence what they teach and the materials they use in class.
The TOEIC serving purposes of graduation, employment or certification in Taiwan, this study indicated that the TOEIC did bring certain impact on students' learning and teachers' teaching. The TOEIC is helpful for students who are passive in English learning, as the test can drive them to study English and improve their overall English proficiency. However, this test-oriented policy might not be of great help for students when they need to use their English skills in real-life communication. It is important to arouse students' interests to learn English and encourage students to use English for daily life communication.

\section{References}

[1] Educational Testing Service (2010).Global use of the TOEIC tests continues to increase as a record-breaking six million tests were administered in 2010. Retrieved December 28, 2012,

[2] fromhttp://www.ets.org/toeic/news/global_use_of_toeic_te

[3] sts_continues_to_increase

[4] Educational Testing Service (n.d.a). TOEIC Report on Test Takers Worldwide-2008. Retrieved December 20, 2012, from http://www.toeic.com.tw/activities/toeic30th/focus- 5.html

[5] Educational Testing Service (n.d.b). What's the TOEIC test?

[6] Retrieved December 30, 2012, from http://www.toeic.com.tw/about_01.jsp

[7] Educational Testing Service (n.d.c). TOEIC speaking and writing tests. Retrieved December 30, 2012, from http://www.toeic.com.tw/sw/about_sw.jsp

[8] Pan, Y. C. (2010). Enhancing students' communicative competency and test-taking skills through TOEIC preparatory materials. TESOL Journal, 81(3), 81-91. 